\title{
Erratum to: Sellarsian Behaviorism, Davidsonian Interpretivism, and First Person Authority
}

\author{
Richard N. Manning
}

Published online: 26 October 2013

(C) Springer Science+Business Media Dordrecht 2013

\section{Erratum to: Philosophia \\ DOI 10.1007/s11406-013-9489-3}

The original version of the article failed to include acknowledgments. The missing information is provided below.

Versions of this paper were delivered to audiences at Ohio University, Denison University, and the University of South Florida. I am grateful to the members of each for their input. I also made significant progress on the paper while funded by the National Endowment for the Humanities at the 2011 Summer Seminar on Quine and Davidson (hosted by Princeton University, Gilbert Harman and Ernest Lepore, directors). Special thanks to Al Martinich and to two anonymous referees of this journal for their helpful comments.

The online version of the original article can be found at http://dx.doi.org/10.1007/s11406-013-9489-3.

R. N. Manning $(\bowtie)$

University of South Florida, Tampa, FL, USA

e-mail: rnmanning@gmail.com 